\title{
A new combination of RT-PCR and reverse dot blot hybridization for rapid detection and identification of potyviruses
}

\author{
Yueh-Chwen Hsu, Tzu-Jung Yeh, Ya-Chun Chang* \\ Department of Plant Pathology and Microbiology, National Taiwan University, No. 1, Sec. 4, Roosevelt Road, Taipei 10617, Taiwan, ROC
}

Received 6 September 2004; received in revised form 5 April 2005; accepted 11 April 2005

Available online 10 May 2005

\begin{abstract}
Three degenerate primers, located at the NIb and CP gene regions, were designed for potyvirus detection. Using these primer pairs, 1.0-1.2 kb cDNA fragments of the 3'-terminal region of six potyviruses were successfully amplified from infected plant tissues. RT-PCR products were sequenced and found to be derived from the expected viruses. To identify further these potyviruses, sequences located between the $3^{\prime}$ end of the NIb gene and the $5^{\prime}$ end of the CP gene were chosen to design a series of species-specific probes. The probes were prepared by PCR with species-specific primers, immobilized onto nylon membrane, and then hybridized with DIG-labeled RT-PCR products amplified by potyvirus degenerate primers. The results suggested that species-specific cDNA probes plus reverse dot blot hybridization was able to identify correctly different species of potyviruses in single as well as mixed infections.
\end{abstract}

(C) 2005 Elsevier B.V. All rights reserved.

Keywords: Potyvirus; Degenerate primer; RT-PCR; cDNA probe; Reverse dot blot hybridization; Identification

\section{Introduction}

The genus Potyvirus (in the family Potyviridae) contains the largest number of plant virus species, including 91 formal species and 88 tentative species (van Regenmortel et al., 2000). Potyviruses cause significant losses in a wide range of crop plants and are transmitted by aphids in a non-persistent manner. Virions of potyviruses are flexuous filaments, $680-900 \mathrm{~nm}$ long and $11-13 \mathrm{~nm}$ wide. The single-stranded, positive-sense RNA genome of potyviruses (ca. $10 \mathrm{~kb}$ ) is polyadenylated at the $3^{\prime}$ end and has a viral genome-linked protein $(\mathrm{VPg})$ covalently linked to the $5^{\prime}$ end. The whole genome encodes a single polyprotein subsequently processed into $9-10$ proteins by three virus-encoded proteinases (van Regenmortel et al., 2000).

Since the 1970s, serological methods especially enzymelinked immunosorbent assay (ELISA) have been used widely and successfully for detection of plant viruses and diagnosis of plant viral diseases (Clark and Adams, 1977; Flegg and

\footnotetext{
* Corresponding author. Tel.: +886 2 33665209; fax: +886 223620271

E-mail address: ycchang@ntu.edu.tw (Y.-C. Chang).
}

Clark, 1979). In the 1990s, nucleic acid-based methods such as reverse transcription (RT) and the polymerase chain reaction (PCR) began to be used in plant virus detection (Wetzel et al., 1991; Rowhani et al., 1995; Thomson and Dietzgen, 1995). Accordingly, several degenerate primers have been designed to recognize the conserved regions of viral genomes of many virus species or the whole virus genus or family (Langeveld et al., 1991; Bateson and Dale, 1995; Tian et al., 1996; Gibbs and Mackenzie, 1997; Chen et al., 2001; Posthuma et al., 2002). Combining the RT-PCR technique and degenerate primers, it is possible to detect many virus species of the same genus or family in a single test, but it cannot distinguish the virus species. Currently, rapid identification of a plant virus is based on ELISA, RT-PCR with specific primers, or cloning and sequencing methods. These investigations are facilitated when some information about the target virus(es) is available.

To overcome this requirement, a new method was developed to identify different potyviruses in a single test, by a method similar to gene or mRNA detection using microarrays (Gerhold et al., 1999; Harrington et al., 2000; Kane et al., 2000; Lockhart and Winzeler, 2000). Species-specific probes 
were immobilized onto nylon membrane, and the virus could then be identified by reverse dot blot hybridization (Lévesque et al., 1998; Martin et al., 2000) using the DIG-labeled RTPCR product amplified from the infected tissue. Experimental results demonstrated that this method has the potential to identify the species of potyviruses in single and mixed infections.

\section{Materials and methods}

\subsection{Virus sources}

Six different potyviruses, one cucumovirus, one potexvirus, one carmovirus and one tobamovirus were used in this study. A potato isolate of Potato virus $Y$ (PVY) and a radish isolate of Turnip mosaic virus (TuMV) were kindly supplied by Dr. Tso-Chi Yang (Taiwan Seed Improvement and Propagation Station, Council of Agriculture) as dehydrated infected leaf tissues and were inoculated and maintained in Nicotiana tabacum var. Samsun and radish (Raphanus sativus), respectively. The remaining viruses are collections in our laboratory. ZAN isolate of Dasheen mosaic virus (DsMV) and ZAN isolate of Zantedeschia mosaic virus (ZaMV) (Chang et al., 2001) originally from calla lily (Zantedeschia spp.) were separately maintained in Philodendron selloum. A papaya isolate of Papaya ringspot virus (PRSV) and a loofah isolate of Zucchini yellow mosaic virus (ZYMV) collected from the experimental farm of National Taiwan University were maintained in papaya (Carica papaya) and zucchini squash (Cucurbita pepo), respectively. Cucumber mosaic virus (CMV) (isolated from New Guinea impatiens), Cymbidium mosaic virus (CymMV) (isolated from orchid), Hibiscus chlorotic ringspot virus (HCRSV) (isolated from hibiscus) and Tobacco mosaic virus (TMV) (isolated from tobacco) were maintained in $N$. benthamiana for CMV and TMV, in orchid (Phalaenopsis spp.) in the case of CymMV and in kenaf (Hibiscus cannabinus) in the case of HCRSV.

\subsection{Plant total RNA extraction}

Leaf tissue $(100 \mathrm{mg})$ was harvested and ground into fine powder in liquid nitrogen, and then transferred to a microfuge tube. Plant total RNAs were extracted from pulverized tissue, according to the protocol of plant total RNA extraction Miniprep system (Viogene, CA, USA).

\subsection{Potyvirus degenerate primer design}

The amino acid sequences of potyviruses were collected from the PIR and Swiss-Prot databases using LOOKUP program in SeqWeb (Accelrys Inc., San Diego, CA, USA). Thirty-three sequences were aligned by PILEUP and PRETTY program in SeqWeb. Several conserved regions were found and the consensus sequence was transferred to the CODEHOP web site (http://blocks.fhcrc.org/blocks/
Table 1

Oligonucleotide primer sequences used in this study

\begin{tabular}{|c|c|}
\hline Primer $^{\mathrm{a}}$ & Sequence $^{\mathrm{b}}$ \\
\hline \multicolumn{2}{|c|}{ Potyvirus degenerate primer } \\
\hline PNIbF1 & 5'GGBAAYAATAGTGGNCAACC $3^{\prime}$ \\
\hline PNIbF5 & $5^{\prime}$ GCCAGCCCTCCACCGTNGTNGAYAA3' \\
\hline PCPR1 & 5'GGGGAGGTGCCGTTCTCDATRCACCA3' \\
\hline \multicolumn{2}{|c|}{ "Potyvirus"-F1 primer } \\
\hline DsMV-F1 & 5'AAATGTGAAGGAGTGCGAACTTCA3' \\
\hline PRSV-F1 & 5'AGTAAGCGTGGGTCAATGGA3' \\
\hline PVY-F1 & 5'TGGATGAGGAAGAGCTGAGAG3' \\
\hline TuMV-F1 & 5'CCAGCTCAAGAAGATCTTACTC $3^{\prime}$ \\
\hline ZaMV-F1 & 5'TCGTGATGCTAATGAGGAGGAG3' \\
\hline ZYMV-F1 & 5'ACTGGCACGATACCTACAAGC3' \\
\hline \multicolumn{2}{|c|}{ "Potyvirus"-R1 primer } \\
\hline DsMV-R1 & 5'AACTTCCTTGCCTTTCTCACTTG3' \\
\hline PRSV-R1 & 5'CTCTCCAGTTTTTGTGCTAGTTG3' \\
\hline PVY-R1 & 5'TGTTCGGGTTTGACTGGATGCT3' \\
\hline TuMV-R1 & 5'TCGCGTTCACCCTCTTCTTG3' \\
\hline ZaMV-R1 & 5'GTGTGTTTGCACTTGTTTGTTC3' \\
\hline ZYMV-R1 & 5'CTTGGCAGCTACTACTGTTTTC3' \\
\hline
\end{tabular}

codehop.html) (Rose et al., 1998). The consensus sequence was first pasted on the multiple alignment processor as FASTA format, then it was reformatted into Blocks Database format by the multiple alignment processor. The Blocks were then used to design the degenerate primers with the temperature setting at $60^{\circ} \mathrm{C}$ and the codon usage table setting at equal. For the degenerate primers located in the $\mathrm{CP}$ region, several suggested primers were obtained and one, which had the lowest degeneration, was selected as the reverse degenerate primer: PCPR1 (Table 1) coding for the conserved sequence WCIENGTSP (Fig. 1). A similar approach was used to design degenerate primers to a conserved sequence in the NIb region: PNIbF1 and PNIbF5 (Table 1) encoding the sequences GNNSGQP and GQPSTVVDN, respectively (Fig. 1).

\subsection{RT-PCR amplification of viral RNA}

For RT reaction, $0.35 \mu \mathrm{g}$ of plant total RNA and $50 \mathrm{pmol}$ PCPR1 primer were added into a microfuge tube, incu-

\begin{tabular}{|c|c|c|c|c|c|c|}
\hline \multirow{2}{*}{\multicolumn{4}{|c|}{ (k) }} & \multicolumn{3}{|c|}{ GNNSGQPSTVVDN } \\
\hline & & & & \multicolumn{2}{|l|}{$6 \mathrm{k} 2$} & WCIENGTSP \\
\hline $5-P 1$ & HC-Pro & P3 & $\mathrm{Cl}$ & $\mathrm{Nla}$ & $\mathrm{Nlb}$ & $\mathrm{CP}-\mathrm{A}(\mathrm{n})$ \\
\hline & & & & $\begin{array}{r}\mathrm{P} \\
\mathrm{P} \\
\text { "pots } \\
\text { potyvirus } \\
\text { "potyvirus }\end{array}$ & $\begin{array}{l}=1 \\
=5 \\
\text { s"-F } \\
\text { prob } \\
\text { prob }\end{array}$ & $\begin{array}{l}\text { 4 PCPR1 } \\
\text { - "potyvirus"-R }\end{array}$ \\
\hline
\end{tabular}

Fig. 1. Schematic representation of the potyvirus genome, showing the relative positions of primers and probes. The positions of potyvirus degenerate primers are shown by triangles, those of species-specific primers and probes are shown by arrows and thick lines, respectively. The corresponding positions and amino acid sequences of degenerate primers are also indicated. 
bated at $65^{\circ} \mathrm{C}$ for $10 \mathrm{~min}$ and then kept on ice for $5 \mathrm{~min}$. The cDNA synthesis reaction was carried out in a total volume of $50 \mu \mathrm{l}$ using AMV reverse transcriptase (Promega, WI, USA), according to the manufacture's instructions. PCR reactions contained $2 \mu \mathrm{l}$ of RT product, 5 pmol PCPR1 primer, 5 pmol PNIbF1 or PNIbF5 primer, 4 nmol dNTPs, 1 U DyNAzyme ${ }^{\mathrm{TM}}$ II DNA polymerase (Finnzymes Inc., Finland), 1X DyNAzyme ${ }^{\mathrm{TM}}$ II DNA polymerase buffer in a total volume of $20 \mu$ l. The PCR reaction was carried out using GeneAmp ${ }^{\circledR}$ PCR system 2400 or 9700 (Perkin-Elmer Applied Biosystems, CA, USA) and an initial incubation at $94^{\circ} \mathrm{C}$ for $5 \mathrm{~min}$ was followed by 35 cycles at $94^{\circ} \mathrm{C}$ for $30 \mathrm{~s}$, $55^{\circ} \mathrm{C}$ for $45 \mathrm{~s}$ and $72^{\circ} \mathrm{C}$ for $1 \mathrm{~min}$, and a final incubation at $72^{\circ} \mathrm{C}$ for $7 \mathrm{~min}$.

\subsection{Cloning and sequencing of cDNA fragments of different potyviruses}

RT-PCR products derived from each potyvirus were examined in $1 \%$ agarose gel and purified by GFX ${ }^{\mathrm{TM}}$ PCR DNA and Gel Band Purification Kit (Amersham Pharmacia Biotech, NJ, USA). The products were cloned into the pGEM-T ${ }^{\circledR}$ Easy vector (Promega, WI, USA). The ligation reaction was set up as suggested by the technical manual, and the products were used to transform Escherichia coli DH5 $\alpha$. Recombinant colonies were detected by blue-white selection (Sambrook and Russell, 2001) and colony PCR.

All clones were sequenced using the ABI PRISM ${ }^{\circledR}$ BigDye $^{\mathrm{TM}}$ terminator cycle sequencing ready reaction kit (Perkin-Elmer Applied Biosystems, CA, USA) and T7 and SP6 primers separately. The sequencing PCR reaction was carried out according to the manufacturer, and clones were sequenced using the ABI PRISM ${ }^{\circledR} 310$ genetic analyzer (Perkin-Elmer Applied Biosystems, CA, USA).

\subsection{Sequence analysis}

Sequence analysis was undertaken using the Wisconsin GCG package version 10.3 and SeqWeb version 1.2 (Accelrys Inc., San Diego, CA, USA). The sequences were assembled by the Fragment Assembly System (FAS) and analyzed through similarity search by BLAST and FASTA programs in Wisconsin package. The amino acid sequences were aligned using the PILEUP and PRETTY programs in SeqWeb.

\subsection{Species-specific probe preparation and immobilization}

The amino acid sequences of the NIb and CP of the six potyviruses were aligned to facilitate the design of speciesspecific primer pairs for each of the six potyviruses (Table 1). The primers were located in a variable region between the $3^{\prime}$ end of the NIb gene and the $5^{\prime}$ end of the CP gene (Fig. 1). Species-specific probes for each virus were prepared by PCR amplification of the corresponding viral cDNA clone. Two probes were prepared for each virus, both contained this variable region. The "potyvirus"-P2 probes (Fig. 1) started from the species-specific forward primer ("potyvirus"-F1, Table 1) and ended at PCPR1 primer; their sizes ranged from 466 to $600 \mathrm{bp}$. Whereas, the "potyvirus"-P3 probes (Fig. 1) started from the species-specific forward primer but ended at the species-specific reverse primer ("potyvirus"R1, Table 1). Probe sizes ranged between 171 and 313 bp.

After gel electrophoresis, the concentration of each probe was measured by the Kodak Digital Science ${ }^{\mathrm{TM}}$ 1D image analysis software (Eastman Kodak Company, NY, USA), and then adjusted to $10 \mathrm{ng} / \mu \mathrm{l}$ before application. The probes were denatured at $94{ }^{\circ} \mathrm{C}$ for $10 \mathrm{~min}$, and then chilled on ice for $5 \mathrm{~min}$. Probes $(0.5 \mu \mathrm{l})$ were transferred to the nylon membrane, the membrane was air-dried, and then UV crosslinking was carried out to immobilize the probes.

\subsection{Target preparation and labeling}

The targets were prepared from total RNA and labeled during the PCR. RT-PCR of plant total RNA was performed with PCPR1/NIbF1 or PCPR1/NIbF5 primers as described previously except $200 \mu \mathrm{M}$ dNTPs was substituted by $1 \times$ PCR DIG labeling mix (Roche Applied Science, Mannheim, Germany). The concentration of targets was adjusted to $6 \mathrm{ng} / \mu \mathrm{l}$ before use.

\subsection{Reverse dot blot hybridization}

The nylon membrane was prehybridized with freshly prepared hybridization solution [50\% formamide, $5 \times$ SSC $(\mathrm{v} / \mathrm{v}), 2 \%$ blocking reagent (w/v) (Roche Applied Science, Mannheim, Germany), $0.1 \% N$-lauroylsarcosine (w/v), $0.02 \% \operatorname{SDS}(\mathrm{w} / \mathrm{v})]$ at $50^{\circ} \mathrm{C}$ for at least $1 \mathrm{~h}$. The target was denatured at $96^{\circ} \mathrm{C}$ for $10 \mathrm{~min}$, and chilled on ice for $5 \mathrm{~min}$ before the addition of $1-5 \mu \mathrm{l}$ target per $10 \mathrm{ml}$ hybridization solution. Hybridization was performed at $50^{\circ} \mathrm{C}$ for at least $6 \mathrm{~h}$, after which, the membrane was washed in $2 \times \mathrm{SSC}, 0.1 \%$ $\mathrm{SDS}$ for $5 \mathrm{~min}$ at room temperature twice. The membrane was then washed in $0.1 \times \mathrm{SSC}, 0.1 \%$ SDS for $15 \mathrm{~min}$ at $68^{\circ} \mathrm{C}$ twice. The membrane could be used directly for detection or air-dried for storage.

The membrane was washed briefly in buffer $1(0.1 \mathrm{M}$ maleic acid, $0.15 \mathrm{M} \mathrm{NaCl}, \mathrm{pH} 7.5$ ), and then incubated in buffer $2(1 \%$ blocking reagent in buffer 1$)$ at room temperature for $30 \mathrm{~min}$. The membrane was incubated in $20 \mathrm{ml}$ diluted antibody-conjugate (Roche Applied Science, Mannheim, Germany; diluted to $75 \mathrm{mU} / \mathrm{ml}$ in buffer 2) at room temperature for $30 \mathrm{~min}$. After incubation, the membrane was washed in buffer 1 at room temperature for $15 \mathrm{~min}$ twice and then incubated in $1 \mathrm{ml}$ CDP-Star solution (Roche Applied Science, Mannheim, Germany) at room temperature for $15 \mathrm{~min}$. The fluorescent signal was detected by sealing the membrane and exposing on X-ray film. 


\section{Results}

\subsection{Specificity of potyvirus degenerate primers}

In order to evaluate the specificity of potyvirus degenerate primers, five viruses belonging to different genus or family were used in RT-PCR tests. Total RNAs were extracted from each virus-infected plants and analyzed by RT-PCR with two pairs of potyvirus degenerate primers, PCRR1/PNIbF1 and PCPR1/PNIbF5 (Table 1 and Fig. 1). These primers corresponded to the conserved sequences located in the NIb and $\mathrm{CP}$ regions, and should react theoretically with all of the potyviruses to give a $1.0-1.2 \mathrm{~kb}$ cDNA product. Accordingly, these primers only generated a specific 1.0 -kb RT-PCR product with ZaMV (potyvirus), they did not amplify any specific product with CMV (cucumovirus), CymMV (potexvirus), HCRSV (carmovirus) and TMV (tobamovirus) (Fig. 2). The

(A)

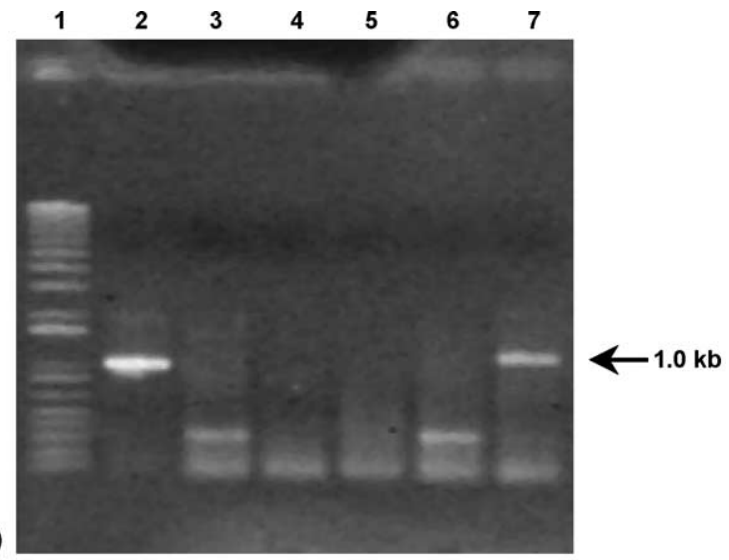

(B)

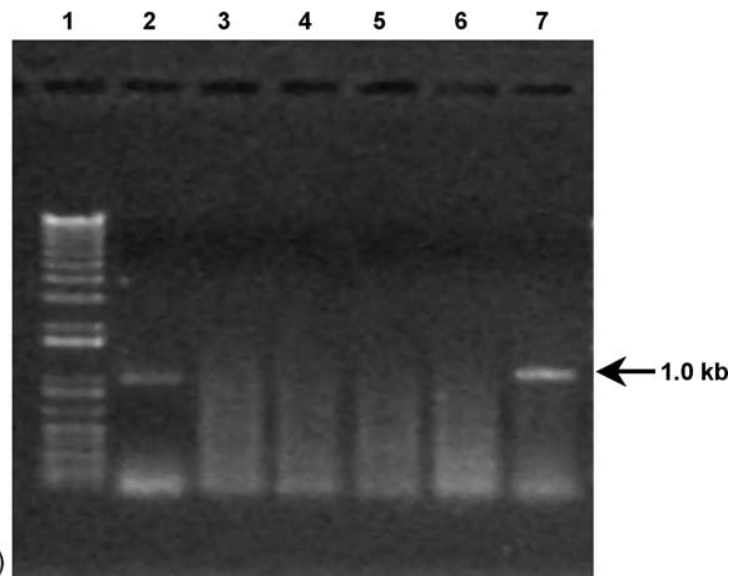

Fig. 2. Specificity of potyvirus degenerate primers by RT-PCR assays on total RNA of different virus-infected plants. Lane 1, $1 \mathrm{~kb}$ Plus DNA Ladder (Invitrogen, CA, USA); lane 2, positive control (cDNA clone of ZaMV); lane 3, CMV-infected Nicotiana benthamiana; lane 4, CymMV-infected orchid (Phalaenopsis sp.); lane 5, HCRSV-infected kenaf (Hibiscus cannabinus); lane 6, TMV-infected $N$. benthamiana; lane 7, ZaMV-infected Philodendron selloum. The RT primer was PCPR1, and two pairs of potyvirus degenerate primers, PCPR1 and PNIbF1 (panel A) and PCPR1 and PNIbF5 (panel B), were used in PCR. The 1.0-kb RT-PCR products of ZaMV identified by $1 \%$ agarose gel electrophoresis are indicated by the arrows.

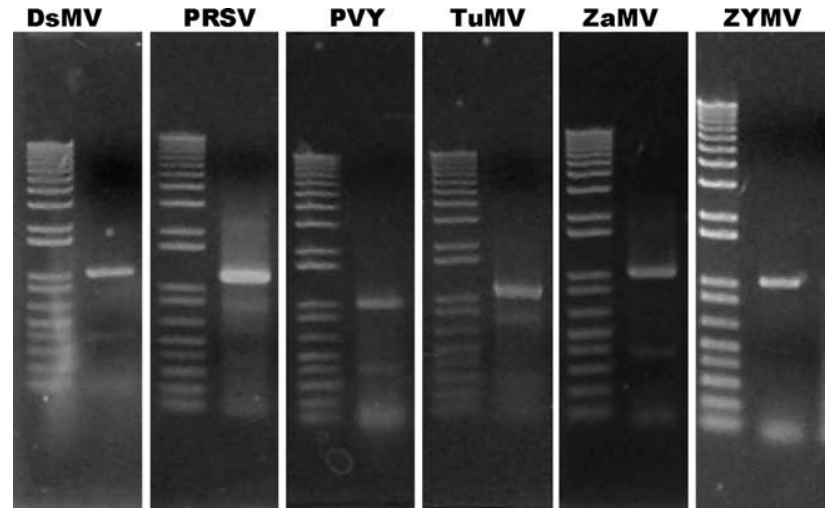

Fig. 3. Different potyviruses detected by RT-PCR and potyvirus degenerate primers. Total RNA of potyvirus-infected plants was extracted and analyzed. The RT primer was PCPR1. The PCR primer pair used to detect PRSV and TuMV was PCPR1/PNIbF1, and the size of the RT-PCR fragment was about $1.2 \mathrm{~kb}$. The PCR primer pair used to detect DsMV, PVY, ZaMV and ZYMV was PCPR1/PNIbF5, and the size of the RT-PCR fragment was about $1.0 \mathrm{~kb}$. The left lane of every panel is $1 \mathrm{~kb}$ Plus DNA Ladder (Invitrogen, CA, USA). RT-PCR products were analyzed in $1 \%$ agarose gel.

0.3-kb cDNA fragments amplified from CMV- and TMVinfected plant total RNAs by PCRR1/PNIbF1 (Fig. 2A) were the nonspecific products of $N$. benthamiana after verified by cloning and sequence analysis (data not shown). The result indicated that these potyvirus degenerate primers had satisfactory specificity because they did not react with nonpotyviruses.

\subsection{Virus detection and cDNA cloning}

To confirm further the application spectrum of these degenerate primers, six different potyviruses were detected separately in inoculated propagation hosts by RT-PCR using PCPR1 as the RT primer and subsequently using PCPR1/PNIbF1 or PCPR1/PNIbF5 as PCR primers. The expected band on the agarose gel after RT-PCR amplification was about $1.0-1.2 \mathrm{~kb}$. PRSV and TuMV had RT-PCR products about $1.2 \mathrm{~kb}$ amplified by PCPR1/PNIbF1 primers (Fig. 3). DsMV, PVY, ZaMV and ZYMV had RT-PCR products about $1.0 \mathrm{~kb}$ amplified by PCPR1/PNIbF5 primers (Fig. 3). In addition, all RT-PCR products were derived from the expected viruses, as confirmed by sequence analysis after cDNA cloning. Accordingly, these potyvirus degenerate primers have the potential to detect the members of the genus Potyvirus.

\subsection{Specificity of the species-specific cDNA probes}

Degenerate primers together with RT-PCR can only detect potyvirus, but cannot identify the species of the virus detected. To overcome this constraint, a new identification method using the species-specific probes and reverse dot blot hybridization was developed. Two types of cDNA probes were prepared for each potyvirus by PCR amplification. The "potyvirus"-P2 probes started from "potyvirus"-F1 primer 
and ended at PCPR1 primer. Whereas, the "potyvirus"-P3 probes started from "potyvirus"-F1 primer and ended at "potyvirus"-R1 primer (Table 1 and Fig. 1). The specificity of the species-specific probes was evaluated by dot blot hybridization. The PCR fragments of each virus clone amplified by PCPR1 and PNIbF1 were applied to a nylon membrane. The DIG-labeled species-specific probes were used for hybridization. The result showed that cross-hybridization was observed in PCR fragments with the P2 probes of PRSV, PVY, TuMV and ZYMV (Fig. 4, left panel). But nonspecific hybridization was found only in the $\mathrm{P} 3$ probes of PRSV (Fig. 4, right panel). The P3 probes have better specificity than that of the $\mathrm{P} 2$ probes according to dot blot hybridization.

\subsection{Virus identification by reverse dot blot hybridization}

Next, these species-specific cDNA probes and revere dot blot hybridization were tested for identifying different potyviruses from infected tissues in a single test. At first, $5 \mathrm{ng}$ of unlabeled P2 and P3 probes were immobilized onto a nylon membrane and each probe had a duplicate (Fig. 5A). The reverse dot blot hybridizations were

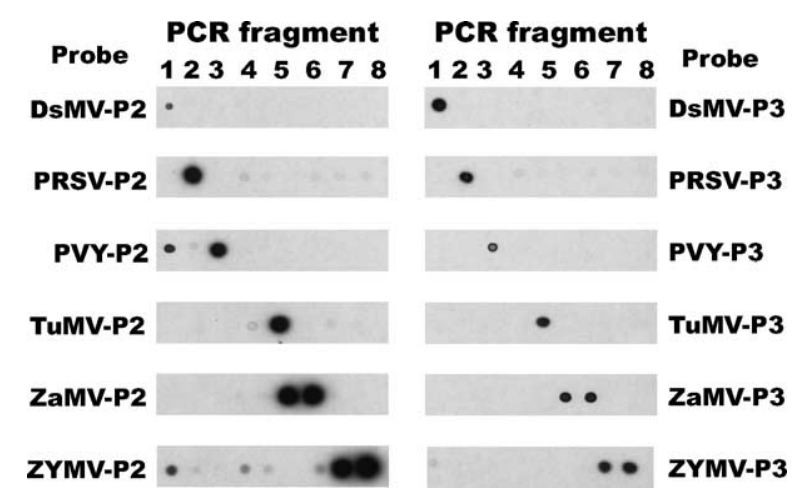

Fig. 4. Specificity of potyvirus species-specific probes by dot blot hybridization. PCR fragments of each virus clone were amplified by PCPR1 and PNIbF1 primers and immobilized on nylon membranes. Dot 1, DsMV; dot 2, PRSV; dot 3, PVY; dot 4, TuMV; dots 5 and 6, ZaMV; dots 7 and 8, ZYMV. Blots were separately hybridized with different $\mathrm{P} 2$ probes (left panels) or $\mathrm{P} 3$ probes (right panels). One microliter of individual PCR fragments and probes were used in dot blot hybridization.

performed by hybridizing with $6 \mathrm{ng}$ of the DIG-labeled targets which were RT-PCR amplified from the infected plant total RNA by potyvirus degenerate primers. The immobilized probes recognized correctly all of the viruses tested,

\begin{tabular}{|l|l|l|l|l|l|}
\hline DSMV-P2 & PRSV-P2 & PVY-P2 & TUMV-P2 & ZaMV-P2 & ZYMV-P2 \\
\hline DsMV-P2 & PRSV-P2 & PVY-P2 & TUMV-P2 & ZaMV-P2 & ZYMV-P2 \\
\hline DSMV-P3 & PRSV-P3 & PVY-P3 & TUMV-P3 & ZaMV-P3 & ZYMV-P3 \\
\hline DsMV-P3 & PRSV-P3 & PVY-P3 & TUMV-P3 & ZaMV-P3 & ZYMV-P3 \\
\hline
\end{tabular}

(A)

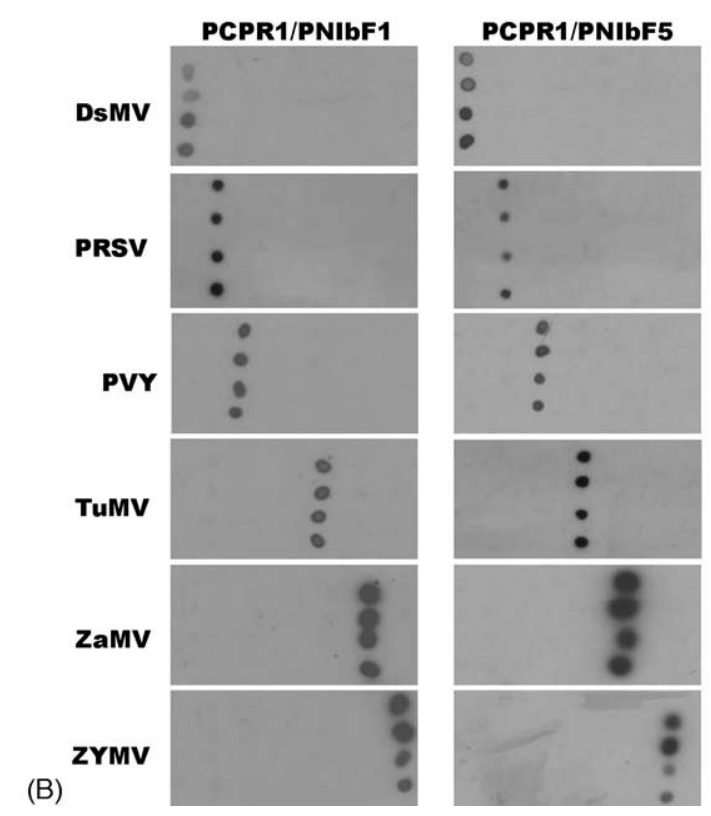

Fig. 5. Identification of DsMV, PRSV, PVY, TuMV, ZaMV and ZYMV by reverse dot blot hybridization. PCPR1 was used as RT primer for total RNA of plants infected by different potyviruses. Subsequent PCR was used to DIG-label the targets using the primers PCPR1/PNIbF1 or PCPR1/PNIbF5. (A) The arrangement of the unlabeled immobilized probes on the nylon membrane. (B) Results of reverse dot blot hybridization of DsMV, PRSV, PVY, TuMV, ZaMV and ZYMV, respectively. Targets were amplified with primers PCPR1/PNIbF1 (left panel) or PCPR1/PNIbF5 (right panel). Five nanogram of each probe and 6 ng of each target were used in reverse dot blot hybridization. 


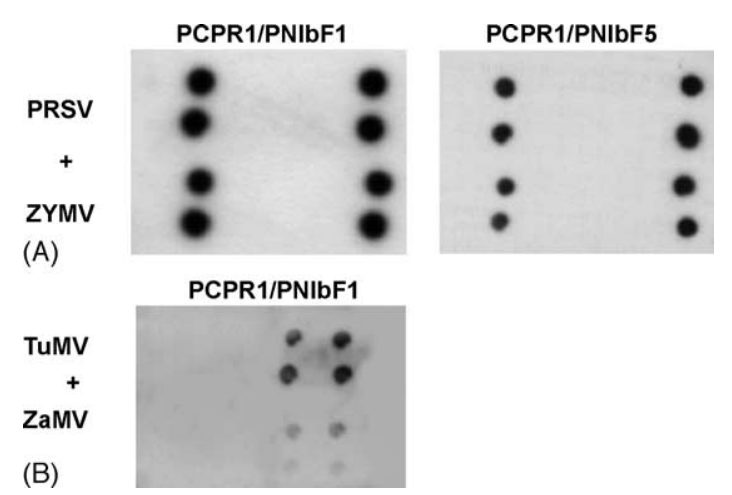

Fig. 6. Identification of potyviruses in artificially and naturally mixed infection samples by reverse dot blot hybridization. Total RNAs from plants separately infected by PRSV and ZYMV were mixed together and then performed reverse dot blot hybridization (panel A). Total RNAs extracted from the plant simultaneously infected by TuMV and ZaMV were also assayed by the same method (panel B). PCPR1 was used as RT primer for both samples. Subsequent PCR was used to DIG-label the targets using the primers PCPR1/PNIbF1 or PCPR1/PNIbF5. The arrangement of the unlabeled immobilized probes on the nylon membrane was the same as Fig. 5A. Five nanogram of each probe and $30 \mathrm{ng}$ of each target were used in reverse dot blot hybridization.

including DsMV, PRSV, PVY, TuMV, ZaMV and ZYMV, irrespective of whether target fragments were amplified with PCPR1/PNIbF1 or PCPR1/PNIbF5 primers (Fig. 5B). Although the previous specificity test showed that the $\mathrm{P} 2$ and P3 probes might hybridize with undesired targets, crosshybridization was not observed in these reverse dot blot hybridizations.

In order to test if this method could identify further different potyviruses in mixed infection, total RNAs extracted separately from PRSV- and ZYMV-infected plants were mixed to mimic mixed infection sample before reverse dot blot hybridization was performed. Target fragments were amplified separately with PCPR1/PNIbF1 and PCPR1/PNIbF5 primers and subsequently hybridized with the blots as previously described. The result demonstrated that both kinds of targets prepared from the mixed total RNAs of PRSV- and ZYMVinfected plants could react with the $\mathrm{P} 2$ and $\mathrm{P} 3$ probes of both viruses (Fig. 6A). Although the result was interesting, it was obtained from a sample mixed artificially. For that reason, a natural mixed infection sample of calla lily was searched since not only DsMV and ZaMV (Chang et al., 2001) but also TuMV could infect calla lily (Chen et al., 2003). Fortunately, a plant infected simultaneously by ZaMV and TuMV was screened by ELISA. This material was used for the preparation of the targets and then hybridized with the blots as before. Since two pairs of primers gave similar results, only the result obtained with PCPR1/PNIbF1 primers was shown. The result indicated that the targets from the mixed infection plant could hybridize with both ZaMV and TuMV cDNA probes although the signals of $\mathrm{P} 3$ probes were weaker than those of $\mathrm{P} 2$ probes (Fig. 6B). These results indicate that this method has the potential to identify the species of potyviruses in mixed infections accurately.

\section{Discussion}

An RT-PCR based method, which has the potential to detect members of the genus Potyvirus by using new designed potyvirus degenerate primers, was developed. Since the amino acid sequence GNNSGQPSTVVDN is highly conserved among potyviruses, the primers PNIbF1 and PNIbF5 that are derived from the $5^{\prime}$ and $3^{\prime}$ region of this coding sequence should amplify any potyvirus, however, more experiments are needed to confirm this possibility. Although similar methods have been described previously by Langeveld et al. (1991), Gibbs and Mackenzie (1997) and Chen et al. (2001), the procedure used in this study was different since two primer pairs were used to avoid false negative results. Accordingly, a potyvirus should be amplified from the RT-PCR method resulting in a product of $1.0-1.2 \mathrm{~kb}$, depending on the size of the $5^{\prime}$ terminus of the CP gene and also the $3^{\prime}$ terminus of the NIb gene, but no specific amplification was observed with cucumovirus, carmovirus, potexvirus and tobamovirus (Fig. 2). Furthermore, using the PCPR1 potyvirus degenerate primer, rather than a dT primer, as the reverse primer for the RT-PCR can avoid the potential problem of interaction with plant poly $(\mathrm{A})^{+}$mRNAs. In fact, the PCPR1 primer always produced fewer nonspecific fragments in preliminary assays (data not shown). The experimental results demonstrated that this method could detect successfully the existence of twelve different potyviruses from the infected plant tissues in addition to DsMV, PRSV, PVY, TuMV, ZaMV and ZYMV (data not shown). Therefore, this RT-PCR method can be used as a rapid detection method for potyviruses.

It is theoretically possible by combining RT-PCR and degenerate primers to detect every member in the genus $\mathrm{Po}$ tyvirus, however, there are limitations in such an approach: since it can neither identify the species of the detected virus(es) nor distinguish single infection from mixed infection. As further identification may be needed, another identification method has been developed. This method adopted the concept of microarray using species-specific probes and reverse dot blot hybridization (Lévesque et al., 1998) to identify the virus(es) directly from infected plant tissues. Recently, Lee et al. (2003) developed a cucurbit-virus chip to detect four tobamoviruses from extracted total RNAs and Boonham et al. (2003) showed the possibility of identifying four potato viruses by microarray technology.

To determine the influence of probe sequence, two sets of species-specific cDNA probes, $\mathrm{P} 2$ and $\mathrm{P} 3$, were designed. During the specificity tests of the probes, the $\mathrm{P} 2$ probes hybridized frequently with other undesired targets, but the P3 probes seldom acted in such way (Fig. 4). This may be due to the $\mathrm{P} 2$ probes covering some conserved sequences of the $\mathrm{CP}$ gene, whereas $\mathrm{P} 3$ probes only represent for the variable region between the NIb and CP genes (Fig. 1). Therefore, it was assumed that the $\mathrm{P} 2$ probes would still have crosshybridization in the reverse dot blot hybridization. Surprisingly, the results showed that such problems could be solved by using the reverse dot blot hybridization approach as the 
$\mathrm{P} 2$ probes had the same specificity as the $\mathrm{P} 3$ probes by this assay (Fig. 5). The reason why dot blot and reverse dot blot had a different specificity may be due to different percentages of conserved sequences were labeled for detection. In other words, the labeled targets in reverse dot blot hybridization had a lower proportion of conserved sequences than the labeled P2 probes in dot blot hybridization and thus these targets did not hybridize with nonhomologus probes. In addition, the experimental results of total RNA derived from potyvirus-infected tissues (Figs. 5 and 6 ) indicated that this method could identify correctly potyvirus(es) in single as well as in mixed infections.

In this study a detection method which can examine whether a plant is infected by potyviruses and an identification method which is capable of identifying species of potyviruses occurring in plant tissues were developed. Therefore, it is possible to identify new hosts of known potyvirus such as TuMV-infected calla lily by these methods. As long as more potyvirus samples become available and the speciesspecific probes for every potyvirus are generated, a complete identification chip (blot) for potyviruses may be obtained in the near future. This novel method will speed up the identification procedure for potyviruses in infected plants. However, most importantly is that this new combination of RT-PCR and reverse dot blot hybridization can be applied to other viruses.

\section{Acknowledgements}

We thank Dr. Chao-Wen Wang for critically reviewing the manuscript. This study was supported by grants (91AS-7.2.2BQ-B4 and 92AS-1.8.2-BQ-B4) from the Bureau of Animal and Plant Health Inspection and Quarantine, the Council of Agriculture, Executive Yuan, Taiwan, the Republic of China.

\section{References}

Bateson, M.F., Dale, J.L., 1995. Banana bract mosaic virus, characterization using potyvirus specific degenerate PCR primers. Arch. Virol. 140, 515-527.

Boonham, N., Walsh, K., Smith, P., Madagan, K., Graham, I., Barker, I., 2003. Detection of potato viruses using microarray technology: towards a generic method for plant viral disease diagnosis. J. Virol. Methods 108, 181-187.

Chang, Y.C., Chen, Y.L., Chung, F.C., 2001. Mosaic disease of calla lily caused by a new potyvirus in Taiwan. Plant Dis. 85, 1289.

Chen, J., Chen, J., Adams, M.J., 2001. A universal PCR primer to detect members of the Potyviridae and its use to examine the taxonomic status of several members of the family. Arch. Virol. 146, 757766.

Chen, C.C., Chao, C.H., Chen, C.C., Yeh, S.D., Tsai, H.T., Chang, C.A., 2003. Identification of Turnip mosaic virus isolates causing yellow stripe and spot on calla lily. Plant Dis. 87, 901-905.
Clark, M.F., Adams, A.N., 1977. Characteristics of the microplate method of enzyme-linked immunosorbent assay for the detection of plant viruses. J. Gen. Virol. 34, 475-483.

Flegg, C.L., Clark, M.F., 1979. The detection of apple chlorotic leafspot virus by a modified procedure of enzyme-linked immunosorbent assay (ELISA). Ann. Appl. Biol. 91, 61-65.

Gerhold, D., Rushmore, T., Caskey, C.T., 1999. DNA chips, promising toys have become powerful tools. Trends Biochem. Sci. 24, 168-173.

Gibbs, A., Mackenzie, A., 1997. A primer pair for amplifying part of the genome of all potyvirids by RT-PCR. J. Virol. Methods 63, 9-16.

Harrington, C.A., Rosenow, C., Retief, J., 2000. Monitoring gene expression using DNA microarrays. Curr. Opin. Microbiol. 3, 285-291.

Kane, M.D., Jatkoe, T.A., Stumpf, C.R., Lu, J., Thomas, J.D., Madore, S.J., 2000. Assessment of the sensitivity and specificity of oligonucleotide (50mer) microarrays. Nucleic Acids Res. 28, 4552-4557.

Langeveld, S.A., Dore, J.M., Memelink, J., Derks, A.F.L.M., van der Vlugt, C.I.M., Asjes, C.J., Bol, J.F., 1991. Identification of potyviruses using the polymerase chain reaction with degenerate primers. J. Gen. Virol. 72, 1531-1541.

Lee, G.P., Min, B.E., Kim, C.S., Choi, S.H., Harn, C.H., Kim, S.U., Ryu, K.H., 2003. Plant virus cDNA chip hybridization for detection and differentiation of four cucurbit-infecting Tobamoviruses. J. Virol. Methods 110, 19-24.

Lévesque, C.A., Harlton, C.E., de Cock, A.W.A.M., 1998. Identification of some oomycetes by reverse dot blot hybridization. Phytopathology $88,213-222$.

Lockhart, D.J., Winzeler, E.A., 2000. Genomics, gene expression and DNA arrays. Nature 405, 827-836.

Martin, R.R., James, D., Lévesque, C.A., 2000. Impacts of molecular diagnostic technologies on plant disease management. Annu. Rev. Phytopathol. 38, 207-239.

Posthuma, K.I., Adams, A.N., Hong, Y., Kirby, M.J., 2002. Detection of Strawberry crinkle virus in plants and aphids by RT-PCR using conserved L gene sequences. Plant Pathol. 51, 266-274.

Rose, T.M., Schultz, E.R., Henikoff, J.G., Pietrokovski, S., McCallum, C.M., Henikoff, S., 1998. Consensus-degenerate hybrid oligonucleotide primers for amplification of distantly related sequences. Nucleic Acids Res. 26, 1628-1635.

Rowhani, A., Maningas, M.A., Lile, L.S., Daubert, S.D., Golino, D.A., 1995. Development of a detection system for viruses of woody plants based on PCR analysis of immobilized virions. Phytopathology 85 , 347-352.

Sambrook, J., Russell, D.W., 2001. Molecular Cloning, A Laboratory Manual,, third ed. Cold Spring Harbor Laboratory Press, Cold Spring Harbor, New York, USA.

Thomson, D., Dietzgen, R.G., 1995. Detection of DNA and RNA plant viruses by PCR and RT-PCR using a rapid virus release protocol without tissue homogenization. J. Virol. Methods 54, 85-95.

Tian, T., Klaassen, V.A., Wisler, G., Duffus, J.E., Falk, B.W., 1996. Generation of cDNAs specific to lettuce infectious yellows closterovirus and other whitefly-transmitted viruses by RT-PCR and degenerate oligonucleotide primers corresponding to the closterovirus gene encoding the heat shock protein 70 homolog. Phytopathology 86, 1167-1173.

van Regenmortel, M.H.V., Fauquet, C.M., Bishop, D.H.L., Carstens, E.B., Estes, M.K., Lemon, S.M., Maniloff, J., Mayo, M.A., McGeoch, D.J., Pringle, C.R., Wickner, R.B., 2000. Virus taxonomy: classification and nomenclature of viruses. In: Seventh Report of the International Committee on Taxonomy of Viruses, Academic Press, San Diego, $1162 \mathrm{p}$.

Wetzel, T., Candresse, T., Ravelonandro, M., Dunez, J., 1991. A polymerase chain reaction assay adapted to plum pox potyvirus detection. J. Virol. Methods 33, 355-365. 